Article

\title{
Digital Financial Inclusion and Sustainable Growth of Small and Micro Enterprises-Evidence Based on China's New Third Board Market Listed Companies
}

\author{
Liu Yang * and Youtang Zhang \\ School of Management, Wuhan University of Technology, Wuhan 430070, China; zyt@whut.edu.cn \\ * Correspondence: yangliu199114@126.com
}

Received: 24 March 2020; Accepted: 1 May 2020; Published: 5 May 2020

\begin{abstract}
The United Nations' 2030 Agenda for Sustainable Development aims to promote inclusive and sustainable economic growth and encourage the formalization and growth of micro, small, and medium enterprises through access to financial services. This study examines the impact and mechanism of the digital financial inclusion on the sustainable growth of small and micro enterprises in China. For this purpose, it uses the data from China's New Third Board Market listed companies from 2011 to 2018 and the digital financial inclusion index of Peking University. The results show that the development of digital financial inclusion helps promote the sustainable growth of small and micro businesses, particularly in private, high-tech industries, and competitive markets. The impact mechanism of this development prevents any financial crisis caused by the capital structure imbalance and capital liquidity problems of small and micro enterprises by alleviating the financing constraints, thus promoting their sustainable growth. The research results show that, under the background of high-quality development of China's economy, continuous promotion of digital financial inclusion and reshaping of the ecological pattern of the financial industry can provide steady financial support for the sustainable growth of small and micro enterprises, and realize the healthy development of micro enterprises and macro economy.
\end{abstract}

Keywords: digital financial inclusion; small and micro enterprises; sustainable growth; Emerging economies

\section{Introduction}

Since 2014, China's economic development has entered a new normal stage with "medium-high speed growth as the basic feature, comprehensive and sustainable social development as the orientation." As the new force of China's economy and social development, small and micro enterprises are important forces to achieve sustainable economic growth and promote inclusive economic development. Under this normal economy, China's small and micro enterprises should receive development opportunities, achieve sustainable growth, and cope with risks and challenges, given the complex changes of the macroeconomic environment and the continuous adjustment of the industrial structure. Currently, the inherent law and operating mechanism of sustainable growth of enterprises remains a problem, with a strong "black box nature" [1]. Most of the existing studies explore the driving factors of sustainable growth of enterprises from the perspectives of macro environment, corporate social responsibility, research and development (R\&D) investment, and management characteristics [2-6], and strive to find the breakthrough of sustainable growth in the combination of "internal factors" and "external factors". The resource-based theory states that an enterprise is a "collection of resources," which determines the speed, mode, and boundaries of its growth. The rapid growth of enterprises will lead to the exhaustion of resources, leading to financial crisis or bankruptcy. Conversely, if the growth 
rate is too slow, resources will be less utilized; thus, the competitiveness and endogenous growth capacity will be lost, leading to a survival crisis of enterprises [7]. Therefore, a sustainable growth of the enterprise can be achieved by coordinating its actual growth with its own resources.

The United Nations' 2030 Agenda for Sustainable Development states that "eradicating poverty in all its forms and dimensions, including extreme poverty, is the greatest global challenge and an indispensable requirement for sustainable development." The 17 Sustainable Development Goals (SDGs) cover three dimensions of sustainable development, namely the economic, social, and environmental dimensions. One of the goals, SDG 8, aims to "promote sustained, inclusive and sustainable economic growth, full and productive employment and decent work for all." It focuses on the realization and guarantee of the rights to employment, education, and financial services for disadvantaged groups, which are composed of farmers, low-income urban residents, the impoverished, and the disabled. This goal advocates for development-oriented policies; it also champions productive activities, decent work, entrepreneurship, creativity, and innovation. In addition, it encourages micro and small businesses to regularize their operations and grow through the promotion of access to banking, insurance, and financial services for all. Against this backdrop, financial inclusion can provide proper, effective financial services to people in need across all walks of life at an affordable cost. Financial inclusion plays an important role in promoting employment, creating a safe and secure working environment, achieving technology upgrades and innovation, and enhancing social equality and harmony.

However, imbalances in financial development and prominent structural contradictions of credit are widespread, owing to an emerging transition economy and continuous evolution of social institutional environment in China [8]. China's small and micro enterprises receive their main resources from a limited number of traditional commercial banks, and their sustainable growth is restricted by the realistic dilemma of "difficult financing and expensive financing." This realistic dilemma can be alleviated by the digital financial inclusion, which is of great value for financial services to the real economy and vulnerable groups. According to the global partnership for financial inclusion (GPFI) white paper released at the G20 Hangzhou summit, digital financial inclusion generally refers to "all actions to promote financial inclusion through digital technology." In October 2017, the report of the 19th National Congress of the Communist Party of China stated that it is necessary to vigorously develop inclusive finance. Thus, the development of digital financial inclusion has become China's national strategy, becoming a transformational momentum for supply structural reform. Digital financial inclusion also drives the power of science and technology of China's digital financial market development, cloud computing and blocks to the dominant distributed computing technology, Internet technology, biological recognition and digital encryption technology, security technology and large data and emerging technologies such as artificial intelligence. The development of digital financial inclusion in China has enabled various types of financial institutions to obtain more information about borrowers through cutting-edge digital technology [9], improved availability of financial resources, reduced cost of financial services, and improved financing efficiency of small and micro enterprises. Therefore, financial inclusion development and its mechanism have a huge impact on the sustainable growth of small and micro enterprises. In turn, this enhances the function of financial services for the Chinese real economy.

This study aims to examine the impact and mechanism of digital financial inclusion on the sustainable growth of small and micro enterprises in China. To this end, this study uses data from of the companies listed on China's New Third Board Market from 2011 to 2018 and the digital financial inclusion index of Peking University. A two-way fixed effects model using instrumental variables and the dynamic GMM method are adopted to test the endogeneity and robustness of the regression results. The results show that the development of digital financial inclusion helps promote the sustainable growth of small and micro businesses, particularly in private, high-tech industries and competitive markets. Further analysis shows that the impact mechanism of the development of digital financial inclusion to further the sustainable growth of small and micro enterprises takes the form of in easing 
the financing constraints of enterprises and preventing the financial crisis triggered by imbalances in the capital structure and unsound capital liquidity.

The significance and contributions of this study are mainly reflected in the following three aspects. First, this article uses the "digital financial inclusion index" provided by the Internet Finance Research Center of Peking University to discuss the impact of digital financial inclusion on the sustainable growth of small and micro enterprises. For the first time, digital financial inclusion is incorporated into the analytical framework of the sustainable growth of enterprises, thereby furthering the knowledge on the factors impacting sustainable growth of enterprises at the macro level. This provides a useful reference for the subsequent empirical research on the development of digital financial inclusion. Secondly, the study tests the impact mechanism of digital financial inclusion regarding financing constraints. Thirdly, it is the first to examine the heterogeneous impact of digital financial inclusion on the sustainable growth of small and micro businesses in different property rights, high-tech properties, and competitive markets, providing detailed empirical evidence for integration of finance and the real economy, and making reasonable sustainable growth decisions. The above findings not only provide important empirical evidence for further development of digital financial inclusion by government departments, but also provide a certain reference value for enterprises to achieve sustainable and healthy development.

This paper is arranged into six parts. The second part is literature review and research hypothesis; the third part is research design, which describes the samples, variables, and models; the fourth part is baseline regression analysis, heterogeneity analysis, endogeneity test, and robustness test; the fifth part is the analysis of action mechanism; and the sixth part is the summary.

\section{Literature Review and Research Hypothesis}

\subsection{Development of Digital Financial Inclusion in China}

The development of digital financial inclusion in China has undergone four stages. (1) Non-profit microcredit in the 1990s: The main sources of funds in this stage were donations or soft loans from individuals or international institutions that were used to alleviate poverty in rural areas. (2) Developmental microfinance from 2000 to 2005: Formal financial institutions were the key sources of funds used to promote re-employment, entrepreneurship, and the improvement of people's livelihoods. (3) Comprehensive and inclusive finance from 2006 to 2010: In this stage, the main sources of funds were village banks and microcredit organizations. Small and micro enterprises were incorporated into the service system to provide financial services such as payments, remittances, lending, and pawning services. (4) Digital financial inclusion from 2011 to the present: Since the "financial inclusion" was first introduced at the Third Plenary Session of the 18th CPC Central Committee, the Chinese government has emphasized it in its work reports for three consecutive years. In July 2017, general secretary Xi Jinping put forward the direction of "building financial inclusion system" and the digital development of financial inclusion for the first time [10]. China's digital financial inclusion is gradually rising into a national strategy. Recently, China's technological and financial services enterprises such as Alibaba Group, Tencent Holdings Ltd., and JD Group have been using their own technological advances to provide financial services such as mobile payment, consumer finance, and online loans for billions of individuals and tens of millions of small and micro enterprises, thus promoting the development of China's network and digital economy. The types of financial resources provided by digital financial inclusion for small and micro enterprises in China mainly include peer-to-peer lending (P2P), online microcredit, internet banking, and internet equity crowdfunding.

Taking online microcredit and internet banking as examples, in 2010, Alibaba Group launched the "Taobao Credit Loan", a financial product, to provide financing services for online store operators. Meanwhile, Alibaba unveiled "Ant Credit Pay" for online shopping consumers. It provides online financing services through the payment link on the shopping page and assesses consumers' personal credit status using big data to speed up the issuance of loans. The "JD Small Loan", a financial product 
provided by the JD Group, provides loans to small and micro agricultural enterprises for the purchase of seeds, fertilizers, and other production inputs, and helps enterprises sell the products on JD.com; the loans are repaid with the profits. We Bank, founded by Tencent, launched two financial products in 2015, namely unsecured small-sum and micro-car loans, which use big data technology to analyze the credit status and consumption behavior of loan applicants. Their focus is on providing financial support to individuals and small and micro enterprises.

The development of digital financial inclusion in China has attracted high hopes and attention globally. Some scholars summarized digital financial inclusion as a third financial financing mode, different from direct and indirect financing [11]. Why did digital financial inclusion take off in China's financial system? The development of mobile Internet and big data technology, the rise of the e-commerce market, the huge enterprise financing gap, and the lag of government regulatory policies are important driving factors for the rapid growth of new forms of digital financial inclusion in China [12]. According to the Digital Financial Inclusion Index (Phase 2) compiled by the Peking University Digital Financial Research Center, China's digital financial inclusion business achieved leapfrog development between 2011 and 2018, with an average annual compound growth rate of $36.4 \%$. However, there are significant differences in the development degree of digital financial inclusion in different regions [13].

\subsection{Digital Financial Inclusion and Sustainable Corporate Growth}

Robert C. Higgins, a senior financial scientist in the United States, first studied the sustainable growth of enterprises from a static perspective. He defined the sustainable growth rate (SGR) as the maximum rate at which a company's sales can grow without depleting its financial resources. This basically implies that the growth of company's sales depends on the increase in its assets, which depends on the growth rate of shareholders' equity, if the company has not changed its operating efficiency and financial policies [14]. According to James · C V Van Horne, "sustainable growth rate is the maximum annual sales growth rate that can be achieved on the basis of pre-established target ratios of operations, debt and dividends" [15]. Several scholars constructed a dynamic sustainable growth model, and made static and dynamic subdivision of the model based on Higgins's sustainable growth model $[16,17]$. While introducing and commenting on the sustainable growth theory and model of Higgins and Van Horn, Chinese scholars further applied and analyzed the sustainable growth model in combination with Chinese enterprise situation [18-20]. Some scholars used the data of Chinese listed companies to expand the sustainable growth model from the perspectives of free cash flow, sustainable profitability, capital cost, and value creation [21-24]. The research on the relationship between enterprise sustainable growth, enterprise environment, and innovation input has gradually attracted the attention of Chinese scholars, because of the in-depth development of China's innovation-driven and green development strategy. This relationship proved to be two-way and interactive, not one-way and static. Therefore, companies can achieve sustainable growth through dynamic adaptation of the internal and external environment [25-27].

The issue of "difficult financing and expensive financing" of small and micro enterprises in China has always been a hot topic of concern and discussion, because it is one of the problems that hinder their sustainable growth $[28,29]$. Under the traditional financial service model, banks and other traditional financial institutions pay more attention to enterprises' hard assets that can be mortgaged [30], making it difficult for small and micro enterprises with less fixed assets, but greater growth potential, to obtain financing [31], thus hindering their sustainable growth. According to a survey on enterprises from the World Bank [32], the loans or credit lines granted to China's enterprises of different sizes are obviously distinct. Small and micro enterprises who have obtained financial support account for only $14 \%$ of all enterprises who have obtained financial support. The main causes of not applying for loans or credit lines are "high collateral requirements", "complicated application procedures", and "inadequate loan amounts and loan periods". As shown in Figure 1, compared to the traditional financial services model, digital financial inclusion has facets such as "higher accessibility of financial services", "wider coverage 
of financial services", "higher efficiency of financial services", and "effective alleviation of information asymmetry between banks and enterprises"; it can therefore support the sustainable growth of small and micro enterprises.

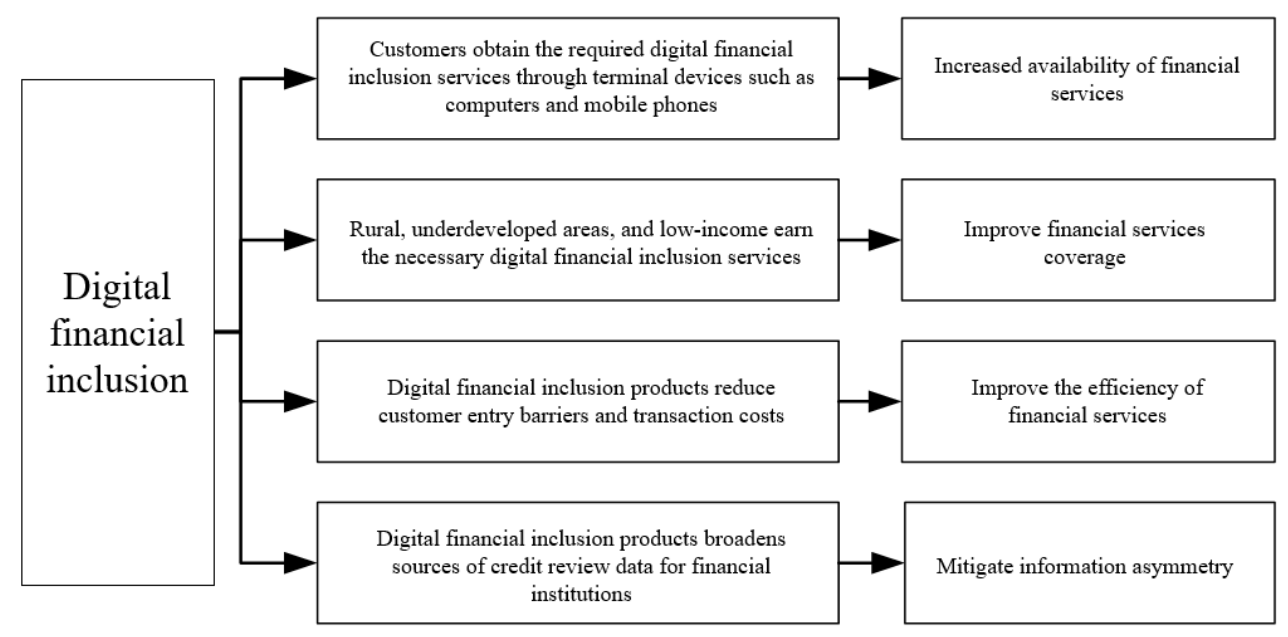

Figure 1. Advantages of digital financial inclusion.

(1) Digital financial inclusion development can improve the accessibility of financial services. Convenient access to financial products and services for small and micro enterprises is the key driver of financial inclusion. The accessibility of financial services varies significantly in China, and it is difficult for small and micro enterprises in remote and less-developed areas to obtain funds in a timely manner through bank branches or ATMs. The lack of accessibility of financial services brings high transaction costs (including direct costs such as transportation costs, and indirect costs such as time costs) to small and micro enterprises. With the development of digital financial inclusion, the basic functions of financial institutions, such as transactions and loan applications, can be handled online, and can thus help small and micro enterprises access financial services and products through digital devices including computers and mobile phones.

(2) Digital financial inclusion development can improve the coverage of financial services. Due to the small scale of the businesses, poor guaranty qualifications, and imperfect credit histories, loan applications of Chinese small and micro enterprises are quite likely to be rejected by traditional financial institutions. In contrast, digital financial inclusion advocates providing appropriate and effective financial services to small and micro enterprises at an affordable cost, which greatly expands the financing channels available to them. For example, MY Bank, an online bank established by Alibaba, mainly provides "small-sum and short-term" loans purely based on credit to small and micro enterprises unable to obtain loans through traditional financial channels and boosts the financing ability of enterprises with supply chain finance models such as stock financing, prepaid financing, and self-factoring.

(3) The development of digital financial inclusion can improve the efficiency of financial services. Digital business models empower traditional financial institutions to use big data and cloud computing as well as other information technologies to collect and analyze a vast amount of customer data. Therefore, they can more accurately design and provide low-cost and highly accessible financial products and services for customers, thus reducing the operating and customer acquisition costs and improving the ability to serve more customers with greater efficiency.

(4) The development of digital financial inclusion can alleviate information asymmetry between banks and enterprises. In general, this type of information asymmetry and transaction costs often make traditional financial institutions reluctant to grant loans to small and micro enterprises. As big data and substitute data (including trade and social data) rapidly grow in popularity, digital financial inclusion can collect business information, systematic behaviors, industry features, external data, 
and personal characteristics of small and micro enterprises. This information can in turn be used to perform credit scoring and risk management, thereby providing appropriate credit lines for small and micro enterprises.

The development of digital financial inclusion can overcome the dependence of traditional finance on physical outlets, have greater geographical penetration, and low-cost advantages, and thus improve the availability of credit funds and the coverage of financial services for small and micro enterprises [33,34]. At the same time, the rapid development of the mobile Internet and the use of emerging technologies such as big data and cloud computing have enabled financial institutions to broaden access to information for small and micro-enterprises, and alleviated information asymmetry between banks and enterprises to a certain extent. Digital financial inclusion products can also enable small and micro enterprises to obtain financial resources support, by reducing the cost and improving the efficiency of financial services [35]. They will also prevent inconsistency between the actual growth of these enterprises and their own financial resources, thus promoting their sustainable growth. We therefore propose hypothesis 1 below:

H1: The development of digital financial inclusion can promote the sustainable growth of small and micro businesses.

\subsection{The Alleviation of Financing Constraints: the Impact Mechanism of Digital Financial Inclusion on the Sustainable Growth of Small and Micro Businesses}

Ideally, capital is able to move freely, and thus enterprises are able to obtain capital based on their own needs. Therefore, the internal and external capital markets are able to substitute each other. However, many of the following studies purport that ideal circumstances do not exist. Due to the information asymmetry and transaction costs in the capital markets, the cost of capital across the internal and external capital markets is different. As a result, enterprises might need to incur a higher cost to obtain external capital, imposing limitations on using the capital. In essence, financing constraints, supported by Modigliani and Miller theory, information asymmetry, and agency theory, reflect the capital structure of an enterprise [36]. Under diverse financing constraints, the sustainable growth rates of enterprises are significantly different, and the financing ability of enterprises plays a decisive role in their sustainable growth $[37,38]$. As the rapid development of an enterprise consumes a significant amount of economic resources, in the absence of sufficient financial support, such growth, would not only be unsustainable, but it could also lead to financial trouble.

Zhou Yean [39] discovers that the shortage of credit resources in the financial markets and capital markets regulation prevent non-state-owned enterprises from obtaining credit resources promptly, which increases financing costs and hinders the sustainable growth of these enterprises. Tan Ruyong [40] finds out that, by examining the connection between external financing and enterprise growth, the total assets of enterprises can be increased by expanding external financing channels, promoting the proportion of external financing assets in total assets, and balancing the structure of diversified financing portfolios. Guo Zeguang and Guo Bing [41], from the perspective of essential balance sheet, incorporate enterprises' financing decisions into the growth management system. When faced with financing constraints, enterprises should prioritize lower-cost debt financing when obtaining external financing and use short-term investments and untapped borrowing capacity to sustain financial flexibility in order to maintain constant growth of their enterprise value.

Many studies have explored the dynamics among the financing approach, financing capability, and growth rate of enterprises. Enterprises need to meet their capital needs to achieve sustainable growth. In general, internal capital alone cannot respond to the demand for new capital. Therefore, enterprises need to bridge the gap through external financing to alleviate the financial burden. If the enterprise is faced with financing constraints in the meantime, such constraints will directly impact investment decisions and restrict scale expansion, crippling the enterprise's sustainable growth and value maximization. However, the inefficiency and distortion of China's financial system is reflected 
in the lack of competitiveness of its commercial banks, leading to high profits of traditional financial institutions, insufficient rural financing, and hindered equity financing channels [42]. This leads to financing constraints for Chinese enterprises. There is significant information asymmetry between traditional financial institutions and small and micro enterprises in China owing to imperfect system and business records. Moreover, the capital cost of internal and external capital markets is different. Therefore, compared with large enterprises, small and micro enterprises may have to pay higher costs to obtain external capital, which imposes certain restrictions on the capital use of the enterprises [43]. Small and micro enterprises are more likely to face a stagnant growth or bankruptcy due to financing constraints. Contrary to the traditional financial products that focus on hard information, such as income, education, and financial statements, digital financial inclusion products can help financial institutions to exclusively use soft information, such as behavior data deposited by lenders on the Internet, and big data analysis to build small and micro enterprises. The credit evaluation model [44-46] that simplifies the credit review process and shortens the information review time to meet the financing needs of small and micro enterprises with "short loan terms, low loan amounts, high loan frequency, and strong loan timeliness." In the P2P network, microfinance loan and third-party payment, such as the suggested digital financial inclusion products, can greatly broaden the financing channels, reduce the threshold of financing and external financing costs for small and micro enterprises, alleviating the financing constraints to promote sustainable growth. Accordingly, we propose hypothesis 2:

H2: Digital financial inclusion can promote the sustainable growth of small and micro businesses by alleviating financing constraints.

\section{Research Design}

\subsection{Sample Selection and Data Source}

The "Decision of the State Council on Issues Related to the National SME Share Transfer System", issued on December 13, 2013, clarified the positioning of the New Third Board. China's New Third Board serves innovative, entrepreneurial, and growing micro-, small-, and medium-sized enterprises to relieve their financing difficulties. All qualified enterprises in China can apply to the host brokerage in order to be listed on the national share transfer system, transfer shares publicly, and pursue equity financing, debt financing, and asset restructuring. This study draws on the practice of Li Chuntao et al. [31] and select the sample from China's New Third Board Market listed companies from 2011 to 2018. The reason for choosing New Third Board Market listed companies is mainly based on the following considerations: (1) Listed companies on New Third Board Market are mainly small- and micro-sized enterprises. (2) There are many listed companies on New Third Board Market, more than 11,000 of which are widely distributed in all provinces and cities across the country, covering regions with different levels of digital financial inclusion. (3) These companies have externally audited financial data. We use the existing research as reference to screen the data as follows: (1) Exclude data on listed companies in the financial sector. In order to ensure the accuracy and robustness of the research results, they are excluded. Compared with other industries, the accounting standards used in the financial industry are relatively special. (2) Exclude the sample of companies with missing main variables, an asset-liability ratio greater than one, and negative owner's equity. Data anomalies and missing from such companies may affect the reliability of the results of this study. (3) This study also performs a $1 \%$ Winsor on the continuous variables to eliminate the effects of extreme values.

It is worth noting that although samples of this study are from the listed companies of China's New Third Board Market, in a sense, the research conclusions can be extended to a wider setting. According to the literature review and research hypotheses, digital financial inclusion at diverse levels in different areas will affect the accessibility, coverage, and efficiency of financial services. It can alleviate information asymmetry between banks and enterprises, thereby relieving financing constraints, broadening financing channels, and reducing financing costs of small and micro enterprises. 
This means when controlling other variables, in the provinces with higher digital financial inclusion index, accessibility of financial services is higher, the coverage of financial services is wider, the efficiency of financial services is better, the information asymmetry is less for small and micro enterprises who as a result can benefit more in the development of digital financial inclusion. More importantly, compared with listed small and micro enterprises, unlisted counterparts face more serious financing constraints. If the development of digital financial inclusion can promote the sustainable growth of small and micro enterprises by alleviating financing constraints, it will be able to play a more vital role in spurring the sustainable growth of these unlisted enterprises.

\subsection{Variable Definitions}

\subsubsection{Explained Variable}

Sustainable growth rate (Sgr): Based on the Higgins model and considering the accessibility of data, the sustainable growth rate model is defined as follows: Sgr $=$ Roi $\times$ Assetturnover $\times$ Re $\times$ Equity, where Roi is the net interest rate on sales; Asset turnover is the total asset turnover rate; Re is the retained rate of return; Equity is the equity multiplier.

\subsubsection{Explanatory Variables}

(1) Digital financial inclusion index (DigitalFin): Digital financial inclusion is an important embodiment of the innovation of financial inclusion in China. In order to better reflect the innovation and development of financial inclusion in all provinces in China, this study uses the Peking University digital financial inclusion index. The index focuses on evaluating the development of digital financial inclusion from the lens of innovative digital finance. It depicts the development level of digital financial inclusion in various provinces, cities, and counties in China from three dimensions, namely the coverage, depth, and digitization level. The index evaluates the coverage of digital finance with the number of electronic accounts (for example, the number of internet payment accounts and bank accounts). It measures the depth of digital finance by taking account of the actual usage of internet financial services including payments, currency funds, credit loans, insurance, investments, and credit services. The index also assesses the digitalization by analyzing the convenience and cost of digital finance. The index is a dimensionless treatment of more than 30 digital inclusive financial indicators, and finally obtained by combining the efficiency coefficient method. At the same time, the method of Liang Bang [29] is used to divide the digital financial inclusion index by 100 to solve the problem that the index is relatively too large.

(2) Financing constraints (Sa): Based on Hadlock and Pierce [47], this study uses the absolute value of Sa index to measure financing constraints. The specific calculation formula is $\mathrm{Sa}=-0.37 \times$ Size $+0.043 \times$ Size $^{2}-0.040 \times$ Age $^{2}$. Among them, Size is the natural logarithm of the enterprise scale; Age is the length of the establishment of the enterprise. The greater the absolute value of Sa index, the higher the degree of financing constraint.

\subsubsection{Control Variables}

This study uses the ratio of net profit to main business income to measure the net profit on sales (Roi). It uses the ratio of the main business revenue to total assets to measure the total asset turnover (Assetturnover). The equity multiplier (Equity) is measured using the total assets and shareholders' equity and the ratio of retained earnings to net profit is used to measure the earnings retention rate (Re). The study further uses the natural logarithm of the total assets to measure company size (Size) and uses the ratio of fixed assets to total assets to measure the asset structure (Ta). The ratio of accumulated depreciation to the total assets is used to measure the tax avoidance (Taxavoid), and the ratio of cash and cash equivalents to total assets is used to reflect the cash holding level of enterprises (Cash). The difference between the sample period year and the year of listing is used to measure the years of listing (Age). In order to control the Year fixed effect, Industry fixed effect and Province fixed effect, 
Year dummy variable (Year), we set the Industry dummy variable (Industry) and Province dummy variable (Province).

\subsection{Empirical Model}

In order to test a series of research hypotheses, we construct the following multiple regression empirical models:

$$
\begin{aligned}
\text { Sgr }_{i, t}=\alpha_{0} & +\alpha_{1} \text { DigitalFin }_{j, t}+\alpha_{2} \text { Roi }_{i, t}+\alpha_{3} \text { Assetturnover }_{i, t}+\alpha_{4} \text { Re }_{i, t} \\
& +\alpha_{5} \text { Equity }_{i, t}+\alpha_{6} \text { Size }_{i, t}+\alpha_{7} \text { Ta }_{i, t}+\alpha_{8} \text { Taxavoid }_{i, t} \\
& +\alpha_{9} \text { Cash }_{i, t}+\alpha_{10} \text { Age }_{i, t}+\alpha_{11} \text { Year }_{t}+\alpha_{12} \text { Industry }_{m} \\
& +\alpha_{13} \text { Province }_{j}+\varepsilon_{i, t} \\
\text { Sa }_{i, t}=\alpha_{0} & +\alpha_{1} \text { DigitalFin }_{j, t}+\alpha_{2} \text { Roi }_{i, t}+\alpha_{3} \text { Assetturnover }_{i, t}+\alpha_{4} \text { Re }_{i, t} \\
& +\alpha_{5} \text { Equity }_{i, t}+\alpha_{6} \text { Size }_{i, t}+\alpha_{7} \text { Ta }_{i, t}+\alpha_{8} \text { Taxavoid }_{i, t} \\
& +\alpha_{9} \text { Cash }_{i, t}+\alpha_{10} \text { Age }_{i, t}+\alpha_{11} \text { Year }_{t}+\alpha_{12} \text { Industry }_{m} \\
& +\alpha_{13} \text { Province }_{j}+\varepsilon_{i, t} \\
\text { Sgr }_{i, t}=\alpha_{0} & +\alpha_{1} \text { DigitalFin }_{j, t}+\alpha_{2} \text { Sa }_{i, t}+\alpha_{3} \text { DigitalFin }_{j, t} \times \text { Sa }_{i, t}+\alpha_{4} \text { Roi }_{i, t} \\
& +\alpha_{5} \text { Assetturnover }_{i, t}+\alpha_{6} \text { Re }_{i, t} \\
& +\alpha_{7} \text { Equity }_{i, t}+\alpha_{8} \text { Size }_{i, t}+\alpha_{7} \text { Ta }_{i, t}+\alpha_{9} \text { Taxavoid }_{i, t} \\
& +\alpha_{10} \text { Cash }_{i, t}+\alpha_{11} \text { Age }_{i, t}+\alpha_{12} \text { Year }_{t}+\alpha_{13} \text { Industry }_{m} \\
& +\alpha_{14} \text { Province }_{j}+\varepsilon_{i, t}
\end{aligned}
$$

where the dependent variable, $S g r_{i, t}$, represents the sustainable growth rate of small and micro enterprises; the explanatory variables mainly include the digital financial inclusion (DigitalFin $j_{j, t}$ ) and financing constraints $\left(S a_{i, t}\right)$, $\mathrm{i}$ is a listed company, $\mathrm{j}$ is a province, $\mathrm{t}$ is time, and $\varepsilon_{i, t}$ is a random error term.

In order to ensure the robustness of the regression results, this study conducts empirical analysis using a two-way fixed effects model. Each regression model has gone through the default robustness standard error procedure. Logarithm analysis is performed on all non-ratio variables and the time, industry, and province fixed effects are controlled. In terms of model setting, model (1) is used to test hypothesis 1 , that is, whether the digital financial inclusion can help promote the sustainable growth of small and micro enterprises. The coefficient of the key explanatory variable (DigitalFin ${ }_{j, t}$ ) represents the impact of digital financial inclusion on the sustainable growth of small and micro enterprises. Based on hypothesis 1 , this coefficient $\alpha_{1}$ is expected to be significantly positive. Model (2) and (3) are designed to test hypothesis 2, that is, whether the digital financial inclusion promotes the sustainable growth of small and micro enterprises by alleviating financing constraints. In model (2), the coefficient of the key explanatory variable (DigitalFin ${ }_{j, t}$ ) shows the impact of digital financial inclusion on the financing constraints of small and micro enterprises. According to hypothesis $2, \alpha_{1}$ is expected to be significantly negative. In model (3), the coefficient of the key explanatory variable $\left(S a_{i, t}\right)$ represents the impact of financing constraints on the sustainable growth of small and micro enterprises. The coefficient of the interaction of digital financial inclusion and financing constraints (DigitalFin $\left.{ }_{j, t} \times S a_{i, t}\right)$ shows the mechanism of digital financial inclusion on the sustainable growth of small and micro enterprises. According to hypothesis 2 , the coefficient $\alpha_{2}$ is expected to be significantly negative and the coefficient $\alpha_{3}$ significantly positive.

\section{Analysis of Benchmark Regression Results}

\subsection{Descriptive Statistics}

Table 1 shows that the maximum value of Sgr for small and micro enterprises in China is 0.438 , the minimum value is 0 , and the standard deviation is 0.070 , indicating that there are obvious differences in the sustainable growth rate, and some small and micro enterprises are weak in sustainable growth 
capacity. The maximum, minimum and average value of digital financial inclusion index are 2.318, 0.185 and 1.498 , respectively, indicating that the development level of digital financial inclusion in each province is significantly different. The maximum and minimum values of the capital structure (Lev) are 0.866 and 0.031 , respectively, indicating that the capital structure of small and micro enterprises in China is significantly different. The maximum and minimum values of the financing constraint (Sa) are -1.256 and 3.344, respectively, indicating that the financing constraint conditions faced by listed companies in China are also quite different.

Table 1. Descriptive statistical results.

\begin{tabular}{cccccc}
\hline Variable & Obs & Mean & Std.Dev & Min & Max \\
\hline Sgr & 10,903 & 0.042 & 0.070 & 0 & 0.438 \\
Digitalfin & 10,903 & 1.498 & 0.363 & 0.185 & 2.318 \\
Lev & 10,903 & 0.406 & 0.207 & 0.031 & 0.866 \\
Sa & 10,903 & 0.568 & 0.965 & -1.256 & 3.344 \\
Roi & 10,903 & 0.045 & 0.285 & -1.906 & 0.513 \\
Asset turnover & 10,903 & 0.867 & 0.556 & 0.065 & 3.261 \\
Re & 10,903 & 0.572 & 1.345 & -8.711 & 3.200 \\
Equity & 10,903 & 2.004 & 1.084 & 1.032 & 7.457 \\
Size & 10,903 & 18.29 & 1.172 & 15.79 & 21.29 \\
Ta & 10,903 & 0.167 & 0.161 & 0.001 & 0.669 \\
Tax avoid & 10,903 & 0.020 & 0.017 & 0 & 0.091 \\
Cash & 10,903 & 0.178 & 0.184 & 0.001 & 0.820 \\
Age & 10,903 & 9.852 & 4.496 & 3 & 22 \\
\hline
\end{tabular}

As shown in Tables 2 and 3, the absolute value of the correlation coefficient of the main variables is less than 0.5 , and the variance inflation factor VIF is less than 10 , indicating that there is basically no multicollinearity among variables, and the selection of each variable is reasonable. 
Table 2. Correlation analysis of major variables.

\begin{tabular}{|c|c|c|c|c|c|c|c|c|c|c|}
\hline & Digitalfin & Roi & Assetturnover & $\operatorname{Re}$ & Equity & Size & Ta & Taxavoid & Cash & Age \\
\hline Digitalfin & 1 & & & & & & & & & \\
\hline Roi & $-0.046^{* * *}$ & 1 & & & & & & & & \\
\hline Assetturnover & $0.118^{* * *}$ & $0.107^{* * *}$ & 1 & & & & & & & \\
\hline $\operatorname{Re}$ & $0.053^{* * *}$ & $-0.036^{* * *}$ & $0.036^{* * *}$ & 1 & & & & & & \\
\hline Equity & $-0.046^{* * *}$ & $-0.123^{* * *}$ & $0.088^{* * *}$ & $-0.112^{* * *}$ & 1 & & & & & \\
\hline Size & -0.00800 & $0.148^{* * *}$ & $-0.179^{* * *}$ & $-0.110^{* * *}$ & $0.242^{* * *}$ & 1 & & & & \\
\hline $\mathrm{Ta}$ & $-0.131^{* * *}$ & $-0.045^{* * *}$ & $-0.199^{* * *}$ & $-0.118^{* * *}$ & $0.114^{* * *}$ & $0.205^{* * *}$ & 1 & & & \\
\hline Taxavoid & $-0.066^{* * *}$ & $-0.070^{* * *}$ & $-0.054^{* * *}$ & $-0.057^{* * *}$ & $0.031^{* * *}$ & -0.0120 & $0.691^{* * *}$ & 1 & & \\
\hline Cash & $0.130^{* * *}$ & $-0.018^{*}$ & $0.050^{* * *}$ & $0.096^{* * *}$ & $-0.259^{* * *}$ & $-0.259^{* * *}$ & $-0.358^{* * *}$ & $-0.202^{* * *}$ & 1 & \\
\hline Age & 0 & $0.071^{* * *}$ & $-0.017^{*}$ & $-0.057^{* * *}$ & 0.0150 & $0.242^{* * *}$ & $0.042^{* * *}$ & $0.020^{* *}$ & $-0.092^{* * *}$ & 1 \\
\hline
\end{tabular}


Table 3. Results of variance inflation factor.

\begin{tabular}{ccc}
\hline Variable & VIF & Tolerance \\
\hline Digitalfin & 1.05 & 0.955 \\
Roi & 1.09 & 0.915 \\
Assetturnover & 1.14 & 0.875 \\
Re & 1.03 & 0.967 \\
Equity & 1.19 & 0.839 \\
Size & 1.34 & 0.748 \\
Cash & 1.26 & 0.793 \\
Taxavoid & 2.04 & 0.491 \\
Age & 1.07 & 0.933 \\
Ta & 2.35 & 0.426 \\
\hline Mean VIF & & \\
\hline
\end{tabular}

\subsection{China's Digital Financial Inclusion Trend Analysis by Region and Year}

Figure 2 exhibits the trend of digital financial inclusion (Digitalfin) in China by year and region. With the cross-border integration of digital technology and financial services and the popularization of mobile Internet technology in China, the development level of digital financial inclusion in the country is on the rise year by year. Despite this rapid growth of digital financial inclusion, the degree of its development varies from one region to the other. In the sample period 2011-2018, the level of digital financial inclusion in eastern China is higher than that in western China, owing to the developed economy, rapid progress of Internet technology and widespread awareness of mobile payment, and there is still more room to catch up in the development of digital financial inclusion in western China.

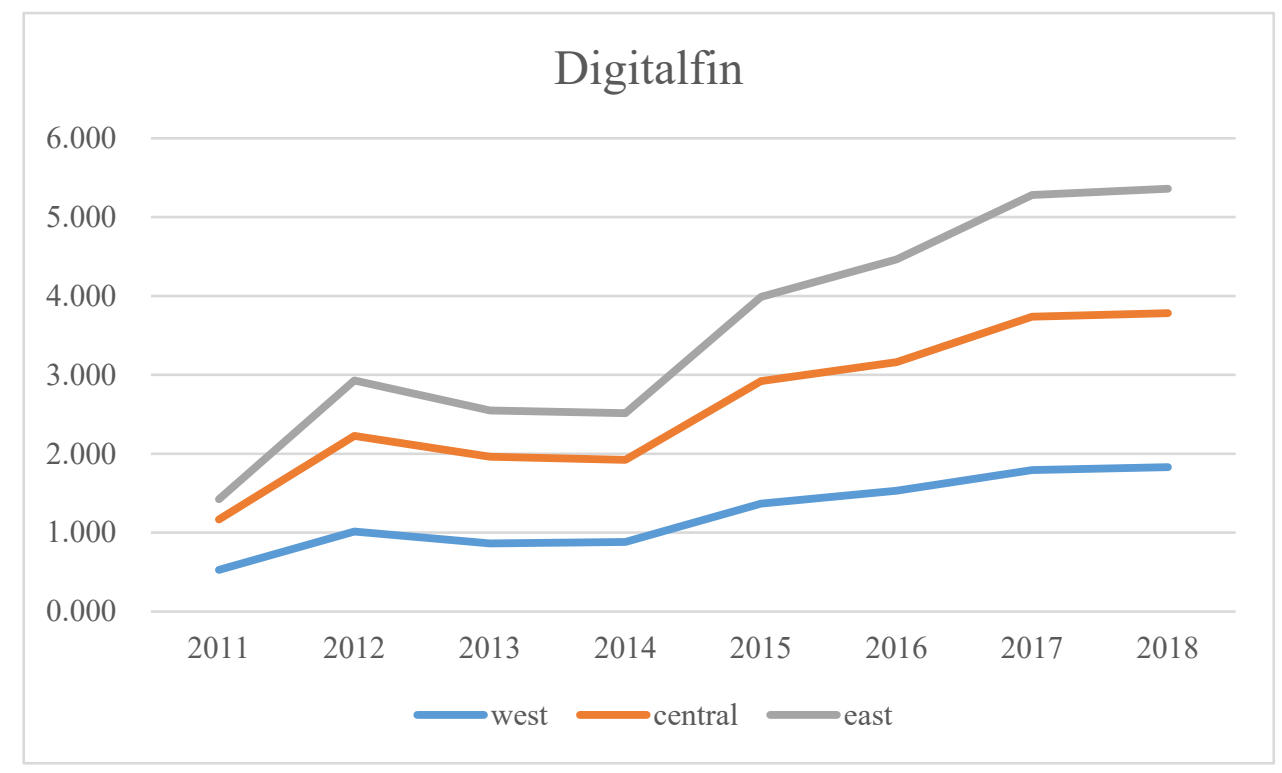

Figure 2. Trends in China's digital financial inclusion by year and region. Data source: Digital financial inclusion index of Peking University (phase II) (2011-2018).

\subsection{Empirical Analysis}

\subsubsection{Digital Financial Inclusion and Sustainable Growth of Small and Micro Businesses}

We first estimate the model. Column (1) of Table 4 shows that the regression coefficient of the digital financial inclusion index (Digitalfin) is significantly positive at the $5 \%$ level. For every $1 \%$ increase in the level of digital financial inclusion, the sustainable growth rate of small and micro enterprises will increase by $2.7 \%$, meaning that the development level of digital financial inclusion is 
conducive to promoting the sustainable growth of small and micro enterprises, thus supporting the hypothesis H1. The development of digital financial inclusion through information technology enables customers to obtain financial services through terminal devices such as computers and mobile phones, expanding the coverage of financial services. Secondly, the innovation of digital financial products reduces the threshold of customer access, the aristocratic attribute of financial services, and the cost of financial services products. Moreover, digital financial inclusion can take advantage of big data technology to reduce information asymmetry between banks and enterprises, improve the speed of credit approval, and enable financial services to accurately locate small and micro enterprises with development potential, although no collateral. This will ease the "urgent need" of enterprises' shortage of operating funds.

The regression coefficients of the net sales margin (Roi), asset turnover rate (Asset turnover) and equity multiplier (Equity) are significantly positive, and the regression coefficients of earnings retention rate $(\mathrm{Re})$ are significantly negative, indicating that the company's operating conditions and financial policies are important factors that affect sustainable corporate growth. The regression coefficients of company size (Size), fixed asset ratio (Ta), non-debt tax shield (Tax avoid), enterprise cash holding level (Cash) and enterprise listing age (Age) are significantly positive, indicating that large enterprises, fixed asset investment, cash holding, and listing experience can promote the sustainable growth of small and micro enterprises. 
Table 4. Benchmark regression results and heterogeneity analysis.

\begin{tabular}{|c|c|c|c|c|c|c|c|c|c|c|c|c|c|c|}
\hline \multirow{4}{*}{ VARIABLES } & \multicolumn{2}{|c|}{ (1) } & \multicolumn{2}{|l|}{ (2) } & \multicolumn{2}{|l|}{ (3) } & \multicolumn{2}{|l|}{ (4) } & \multicolumn{2}{|c|}{ (5) } & \multicolumn{2}{|l|}{ (6) } & \multicolumn{2}{|l|}{ (7) } \\
\hline & \multicolumn{2}{|c|}{ Total sample } & \multicolumn{2}{|c|}{ Private enterprise } & \multicolumn{2}{|c|}{$\begin{array}{l}\text { State-owned } \\
\text { enterprise }\end{array}$} & \multicolumn{2}{|c|}{ High-tech industry } & \multicolumn{2}{|c|}{$\begin{array}{l}\text { Non high-tech } \\
\text { industry }\end{array}$} & \multicolumn{2}{|c|}{ Monopoly industry } & \multicolumn{2}{|c|}{$\begin{array}{l}\text { Non-monopoly } \\
\text { industry }\end{array}$} \\
\hline & \multicolumn{2}{|c|}{ Sgr } & \multicolumn{2}{|c|}{ Sgr } & \multicolumn{2}{|c|}{ Sgr } & \multicolumn{2}{|c|}{ Sgr } & \multicolumn{2}{|c|}{ Sgr } & \multicolumn{2}{|c|}{ Sgr } & \multicolumn{2}{|l|}{ Sgr } \\
\hline & Coefficient & t-ratio & Coefficient & t-ratio & Coefficient & t-ratio & Coefficient & t-ratio & Coefficient & t-ratio & Coefficient & t-ratio & Coefficient & t-ratio \\
\hline Digitalfin & $0.027^{* *}$ & 2.07 & $0.255^{*}$ & 2.04 & 0.016 & 1.29 & $0.039^{*}$ & 1.96 & 0.019 & 0.97 & 0.007 & 0.41 & $0.054^{* *}$ & 2.22 \\
\hline Roi & $0.011^{* * *}$ & 4.82 & $0.069^{*}$ & 2.04 & $0.010^{* * *}$ & 4.53 & $0.008^{* * *}$ & 2.90 & $0.014^{* * *}$ & 4.00 & $0.014^{* * *}$ & 3.70 & $0.011^{* * *}$ & 4.69 \\
\hline Asset turnover & $0.007^{* * *}$ & 4.28 & 0.002 & 0.22 & $0.007^{* * *}$ & 4.02 & $0.008^{* * *}$ & 3.14 & $0.007^{* * *}$ & 3.14 & $0.009^{* * *}$ & 4.04 & $0.005^{* *}$ & 2.21 \\
\hline $\operatorname{Re}$ & $-0.015^{* * *}$ & -9.49 & $-0.013^{* * *}$ & -3.90 & $-0.015^{* * *}$ & -9.69 & $-0.017^{* * *}$ & -8.44 & $-0.014^{* * *}$ & -7.29 & $-0.014^{* * *}$ & -7.23 & $-0.017^{* * *}$ & -8.64 \\
\hline Equity & $0.022^{* * *}$ & 11.42 & $0.019^{* * *}$ & 4.10 & $0.022^{* * *}$ & 10.28 & $0.019^{* * *}$ & 8.97 & $0.024^{* * *}$ & 10.62 & $0.023^{* * *}$ & 12.53 & $0.020^{* * *}$ & 8.08 \\
\hline Size & $0.004^{* * *}$ & 7.85 & -0.000 & -0.04 & $0.004^{* * *}$ & 8.48 & $0.004^{* * *}$ & 6.37 & $0.004^{* * *}$ & 4.74 & $0.005^{* * *}$ & 5.39 & $0.003^{* * *}$ & 7.31 \\
\hline $\mathrm{Ta}$ & $0.019 * * *$ & 2.87 & 0.014 & 0.30 & $0.019 * * *$ & 2.96 & $0.034^{* * *}$ & 3.88 & 0.007 & 0.88 & $0.014^{*}$ & 1.86 & $0.025^{* * *}$ & 3.32 \\
\hline Tax avoid & $0.197^{* * *}$ & 3.74 & 0.105 & 0.27 & $0.203^{* * *}$ & 3.96 & 0.114 & 1.18 & $0.259^{* * *}$ & 5.10 & $0.203^{* * *}$ & 3.94 & $0.196^{* *}$ & 2.33 \\
\hline Cash & $0.028^{* * *}$ & 5.51 & 0.005 & 0.20 & $0.028^{* * *}$ & 5.25 & $0.025^{* * *}$ & 3.75 & $0.032^{* * *}$ & 6.47 & $0.032^{* * *}$ & 4.77 & $0.025^{* * *}$ & 3.53 \\
\hline Age & $0.001^{* * *}$ & 4.79 & 0.001 & 0.55 & $0.001^{* * *}$ & 5.23 & $0.001^{* * *}$ & 4.24 & $0.001^{* *}$ & 2.69 & $0.000^{* *}$ & 2.34 & $0.001^{* * *}$ & 3.88 \\
\hline Constant & $-0.103^{* * *}$ & -6.10 & -0.162 & -1.29 & $-0.094^{* * *}$ & -5.61 & $-0.130^{* * *}$ & -5.87 & $-0.087^{* * *}$ & -3.45 & $-0.102^{* * *}$ & -4.27 & $-0.102^{* * *}$ & -5.05 \\
\hline Time effect & \multicolumn{2}{|c|}{ YES } & \multicolumn{2}{|c|}{ YES } & \multicolumn{2}{|c|}{ YES } & \multicolumn{2}{|c|}{ YES } & \multicolumn{2}{|c|}{ YES } & \multicolumn{2}{|c|}{ YES } & \multicolumn{2}{|l|}{ YES } \\
\hline Industry effect & \multicolumn{2}{|c|}{ YES } & \multicolumn{2}{|c|}{ YES } & \multicolumn{2}{|c|}{ YES } & YES & & YES & & YES & & YES & \\
\hline Province effect & YES & & YES & & YES & & YES & & YES & & YES & & YES & \\
\hline Observations & 10,90 & & 434 & & 10,46 & & 5,36 & & 5,53 & & 5,69 & & 5,208 & \\
\hline R-squared & 0.26 & & 0.407 & & 0.265 & & 0.23 & & 0.29 & & 0.29 & & 0.239 & \\
\hline
\end{tabular}

Robust t-statistics in parentheses ${ }^{* * *} p<0.01,{ }^{* *} p<0.05,{ }^{*} p<0.1$. 
4.3.2. Heterogeneous Analysis of the Sustainable Growth of Small and Micro Enterprises Promoted by Digital Financial Inclusion

The development of digital financial inclusion can effectively promote the sustainable growth of small and micro enterprises. However, this may vary for different types of enterprises, subject to the property right nature, high-tech attributes, and degree of competition. To study the effects of the digital financial inclusion in different property rights enterprises, we group the samples according to the nature of property rights and divide them into two sets of data: state-owned and private enterprises. In the context of "financial repression" in China, the financial system is dominated by the government, and there is a natural political connection between state-owned enterprises and state-owned banks, which occupies an obvious advantage in obtaining credit resources [48]. At the same time, when formulating industrial policies, the government will prioritize the state-owned enterprises [49]. In the traditional financial market, private enterprises face more stringent credit audit; it is more difficult to obtain credit funds through formal financial channels. As a result, private enterprises have a stronger desire to seek financial support through Internet channels and a higher degree of dependence. The empirical results in Columns (2) and (3) of Table 4 show that the regression coefficient of the Digitalfin in the sample of private enterprises is 0.255 , which is significantly positive. The regression coefficient of Digitalfin of state-owned enterprises is not significant. It indicates that digital financial inclusion may play a more significant role in promoting the sustainable growth of small and micro enterprises for private enterprises.

To study the differential effect of digital financial inclusion on promoting the sustainable growth of small and micro enterprises in different industries, the samples are grouped according to the high-tech attributes of the industry, and divided into two groups of data of high-tech and non-high-tech industry. Enterprises in high-tech industry are pressurized by fierce market competition and therefore depend more on $\mathrm{R} \& \mathrm{D}$ for a new product than traditional industries. The innovation investment is long-term and continuous, and it depends on the promotion of a large amount of funds. Its high failure rate and unpredictable returns make high-tech companies vulnerable to funding pressure. The limited and unstable cash flow generated in the innovation process of the company is not enough to maintain the capital demand of the innovation project, and the enterprise may be hit by random cash flow at any time, thus affecting the sustainable growth of the enterprise [50]. The empirical results in Column (4) and (5) in Table 4 show that the regression coefficient of Digitalfin in high-tech industry samples is 0.039 , which is significantly positive. In non-high-tech industries, this coefficient is not significant, indicating that the role of digital financial inclusion in promoting the sustainable growth of small and micro enterprises may be more significant for high-tech industries.

To study the differential effect of digital financial inclusion on promoting the sustainable growth of small and micro businesses in different competitive markets, the samples are grouped according to the industry $\mathrm{HHI}$ and divided into two groups of data: competitive and non-competitive market. Previous studies have found that product market competition can be used as an external mechanism of corporate governance. Not only does the market competition enables company decision makers to obtain more information and reduce supervision costs, but also directly supervises managers through the threat of bankruptcy and liquidation [51-54], so as to improve the enterprise operating conditions, and promote the sustainable growth of enterprises. In a competitive market, the degree of market information asymmetry is greatly reduced, enterprise decision makers are faced with low information barriers, and the competitive environment provides objective conditions for the improvement of organizational cognition [55]. The empirical results in Columns (6) and (7) of Table 4 show that the regression coefficient of Digitalfin in the competitive market sample is 0.054 , which is significantly positive. However, that of non-competitive market samples is not significant, indicating that digital financial inclusion plays a more significant role in promoting the sustainable growth of small and micro enterprises in a competitive market. 


\subsection{Endogeneity Test}

Our study verified the impact of digital financial inclusion on the sustainable growth of small and micro businesses. To avoid the measurement errors of missing variables or digital financial inclusion, which may lead to errors in the estimated results and generate endogenous problems, this study first refers to Wang Xiaoliang [56] to re-examine the relationship between digital financial inclusion and the sustainable growth of small and micro enterprises, using the generalized matrix estimation (GMM) method. Column (1) in Table 5 shows that the coefficient of Digitalfin is 0.016, which is significantly positive at the level of $1 \%$. Secondly, the study uses the proportion of Internet users in China's provinces as a tool variable and uses 2SLS (two-stage) regression analysis. The instrumental variable conforms to the two constraints of correlation and endogeneity. On the one hand, the higher the proportion of Internet users in the total population, the better the coverage and depth of digital financial inclusion; on the other hand, the proportion of Internet users in the total number has little impact on the sustainable growth capacity of small and micro enterprises. The results of Columns (2) and (3) in Table 5 show that the regression coefficient of the proportion of Internet users to the total (Inter) number was significantly positive, and the F statistic of the regression results of the first stage met the basic requirements of instrumental variables. Furthermore, the regression results of the second stage show that the Digitalfin coefficient is 0.053 , which is significantly positive at the $5 \%$ level, indicating that digital financial inclusion can significantly promote the sustainable growth of small and micro enterprises, which is completely consistent with the previous results.

Table 5. Endogenous test results.

\begin{tabular}{|c|c|c|c|c|c|c|}
\hline \multirow{5}{*}{ Variables } & \multicolumn{2}{|c|}{ (1) } & \multicolumn{2}{|c|}{ (2) } & \multicolumn{2}{|c|}{ (3) } \\
\hline & \multicolumn{2}{|c|}{ Dynamic GMM } & \multicolumn{4}{|c|}{ 2SLS Regression } \\
\hline & & & \multicolumn{2}{|c|}{ First } & \multicolumn{2}{|c|}{ Two } \\
\hline & \multicolumn{2}{|c|}{ sgr } & \multicolumn{2}{|c|}{ Digitalfin } & \multicolumn{2}{|c|}{ sgr } \\
\hline & Coefficient & t-ratio & Coefficient & t-ratio & Coefficient & t-ratio \\
\hline L.sgr & $0.079^{*}$ & 1.89 & & & & \\
\hline Digitalfin & $0.016^{* * *}$ & 3.35 & & & $0.053^{* *}$ & 3.12 \\
\hline Inter & & & $2.314^{* * *}$ & 20.82 & & \\
\hline Control Variables & \multicolumn{2}{|c|}{ YES } & \multicolumn{2}{|c|}{ YES } & \multicolumn{2}{|c|}{ YES } \\
\hline Constant & $0.211^{* *}$ & 2.08 & $-0.189^{* * *}$ & -4.84 & $-0.117^{* * *}$ & -4.14 \\
\hline Observations & \multicolumn{2}{|c|}{3560} & \multicolumn{2}{|c|}{10,903} & \multicolumn{2}{|c|}{10,903} \\
\hline R-squared & & & \multicolumn{2}{|c|}{0.994} & \multicolumn{2}{|c|}{0.268} \\
\hline F statistics & & & \multicolumn{2}{|c|}{$496.3^{* * *}$} & \multicolumn{2}{|c|}{$407.54^{* * *}$} \\
\hline AR1 (P-value) & \multicolumn{2}{|c|}{$-2.476^{* *}$} & & & & \\
\hline AR2 (P-value) & \multicolumn{2}{|c|}{-0.399} & & & & \\
\hline Sargan & \multicolumn{2}{|c|}{$19.988(0.172)$} & & & & \\
\hline
\end{tabular}

\subsection{Robustness Check}

To ensure the reliability of the conclusion, this study further conducts the following robustness tests, as shown in Table 6. (1) Control the level of financial development: The level of regional financial development often affects the channels for enterprises to obtain external financing [57]. In regions with relatively complete financial development, the approval and supervision costs of financing for small and micro enterprises are relatively low [58], which may affect the promotion effect of digital financial inclusion on the sustainable growth of these enterprises. Based on this, this study uses the 
ratio of bank deposits to regional GDP to measure the level of financial development. The financial development level is generated as a dummy variable (Dumfin) according to the median. The financial development level (Dumfin) is better taken as 1, otherwise it is taken as 0 , and the regression is carried out again. The results in Table 6 (1) show that, after controlling the influence of regional financial development level (Dumfin), digital financial inclusion still plays a significant role in promoting the sustainable growth of small and micro enterprises. (2) Remeasurement of sustainable growth rate: Considering the difference in the sustainable growth rate of the industry, the enterprise sustainable growth rate (Sgr) is obtained after subtracting it from the average annual sustainable growth rate of the industry to obtain the adjusted enterprise sustainable growth rate (Adjsgr). In Column (2) of Table 6, the coefficient of Digitalfin is significantly positive. (3) Remeasurement of digital financial inclusion: The Digitalfin is used to divide the sample into the better and the worse digital financial inclusion group according to the median. The dummy variable DumDigitalfin is set. Take 1 for the group larger than the median and 0 for the array smaller than the median and substitute it into the model for regression again. The regression conclusion remains unchanged. Therefore, the benchmark regression structure in this paper is robust.

Table 6. Robustness test results.

\begin{tabular}{|c|c|c|c|c|c|c|}
\hline \multirow{3}{*}{ Variables } & \multicolumn{2}{|c|}{ (1) } & \multicolumn{2}{|c|}{ (2) } & \multicolumn{2}{|c|}{ (3) } \\
\hline & \multicolumn{2}{|c|}{ Sgr } & \multicolumn{2}{|c|}{ Adjsgr } & \multicolumn{2}{|c|}{ Sgr } \\
\hline & Coefficient & t-ratio & Coefficient & t-ratio & Coefficient & t-ratio \\
\hline Digitalfin & $0.037^{*}$ & 1.92 & $0.022^{*}$ & 1.82 & & \\
\hline Dumfin & $-0.010^{*}$ & -1.91 & & & & \\
\hline DumDigitalfin & & & & & $0.027^{* *}$ & 2.07 \\
\hline Control Variables & \multicolumn{2}{|c|}{ YES } & \multicolumn{2}{|c|}{ YES } & \multicolumn{2}{|c|}{ YES } \\
\hline Constant & $-0.109^{* * *}$ & -4.74 & $-0.121^{* * *}$ & -7.76 & $-0.103^{* * *}$ & -6.10 \\
\hline Observations & \multicolumn{2}{|c|}{10,903} & \multicolumn{2}{|c|}{10,903} & \multicolumn{2}{|c|}{10,903} \\
\hline R-squared & \multicolumn{2}{|c|}{0.268} & \multicolumn{2}{|c|}{0.236} & \multicolumn{2}{|c|}{0.268} \\
\hline
\end{tabular}

\section{Impact Mechanism Analysis}

The previous research concludes that the development of digital financial inclusion promotes the sustainable growth of small and micro enterprises, and this varies subject to property rights, high-tech properties, and competitive markets. To further explore the impact mechanism of digital financial inclusion on the sustainable growth of small and micro enterprises, this study takes financing constraints as the starting point for further analysis.

According to the results in Table 7 (1), the Digitalfin coefficient is -0.071 , which is significantly negative, indicating that the development of digital financial inclusion can alleviate the financing constraints faced by enterprises. The results in Column (2) show that the coefficient of financing constraint (Sa) is significantly negative, indicating that the financing constraint faced by enterprises restricts the sustainable growth of small and micro enterprises. The results in Column (3) show that the interaction coefficient between digital financial inclusion index and financing constraints (Digital financial * Sa) is significantly positive, which indicates that the development of digital financial inclusion promotes the sustainable growth of small and micro enterprises by easing financing constraints, thus supporting the hypothesis H2. This is because digital financial inclusions rely on information technology, big data technology, and cloud computing to further expand the reach and scope of its applications. China's new digital financial service products represented by Alipay and Ant Financial provide small and micro enterprise users with a wide range of financial services such 
as payment, credit, insurance, investment, currency funds and credit services. This helps to solve the information asymmetry in small micro enterprise financing problems to improve the efficiency of capital allocation, because so many small micro enterprise financing constraints provide diversified financing channels. Financing further abundance can relieve excessive growth to a certain extent, brought about by the financial resource shortage, and ensure the sustainable development of enterprise.

Table 7. Mechanism of digital financial inclusion, promoting the sustainable growth rate of small and micro enterprises, based on financing constraints.

\begin{tabular}{|c|c|c|c|c|c|c|}
\hline \multirow{3}{*}{ Variables } & \multicolumn{2}{|c|}{ (1) } & \multicolumn{2}{|c|}{ (2) } & \multicolumn{2}{|c|}{ (3) } \\
\hline & \multicolumn{2}{|c|}{ Sa } & \multicolumn{2}{|c|}{ Sgr } & \multicolumn{2}{|c|}{ Sgr } \\
\hline & Coefficient & t-ratio & Coefficient & t-ratio & Coefficient & t-ratio \\
\hline Digitalfin & $-0.071^{*}$ & -1.41 & & & $0.026^{*}$ & 1.94 \\
\hline Sa & & & $-0.005^{* * *}$ & -4.41 & $-0.007^{*}$ & -1.86 \\
\hline Digitalfin*Sa & & & & & $0.001^{*}$ & 1.38 \\
\hline Control Variables & \multicolumn{2}{|c|}{ YES } & \multicolumn{2}{|c|}{ YES } & \multicolumn{2}{|c|}{ YES } \\
\hline Constant & $-7.542^{* * *}$ & -12.38 & $-0.131^{* * *}$ & -8.07 & $-0.144^{* * *}$ & -6.85 \\
\hline Observations & \multicolumn{2}{|c|}{10,903} & \multicolumn{2}{|c|}{10,903} & \multicolumn{2}{|c|}{10,903} \\
\hline R-squared & \multicolumn{2}{|c|}{0.578} & \multicolumn{2}{|c|}{0.269} & \multicolumn{2}{|c|}{0.269} \\
\hline
\end{tabular}

\section{Research Conclusions and Countermeasures}

\subsection{Research Conclusions}

The rapid development of digital technology has promoted the integration of finance and technology, has given birth to a series of new financial forms, and brought great changes to human social life. Promoting inclusive and sustainable economic growth and encouraging micro-sized, small, and medium-sized enterprises to formalize and grow through access to financial services is a development goal of the United Nations' 2030 Agenda for Sustainable Development. Our study has therefore investigated the impact of digital financial inclusion in China on the sustainable growth of small and micro businesses. The study uses the data of listed companies on New Third Board Market of China from 2011 to 2018 and the digital financial inclusion index of Peking University to empirically test the impact of digital financial inclusion development and mechanism in various provinces of China. The study finds that: (1) the development of digital financial inclusion helps promote the sustainable growth of small and micro enterprises. (2) In contrast, the development of digital financial inclusion can effectively promote the sustainable growth of small and micro enterprises in the private nature, high-tech industry, and competitive market. (3) The impact mechanism of the development of digital financial inclusion to promote the sustainable growth of small and micro enterprises lies in by easing the financing constraints of enterprises. It prevents the financial crisis caused by the imbalance of capital structure and capital liquidity, thus promoting the sustainable growth of small and micro enterprises. The results show that, under the background of high-quality economic development in China, digital financial inclusion and reshaping of the ecological pattern of the financial industry can provide a steady stream of financial support for the sustainable growth of small and micro enterprises. Moreover, micro enterprises may realize a healthy development and macro economy.

\subsection{Policy Proposal}

Based on the research results of this paper, we propose the following policy suggestions: first, the government should promote the healthy development of digital financial inclusion. In the critical period of the transformation of China's economy from high-speed growth to high-quality development, 
the government should actively comply with the trend of rapid development of digital financial inclusion. It should promote the construction of diversified financial services and realize the accurate connection between digital financial inclusion and small and micro enterprises to reduce the financial service threshold. Moreover, the government should promote small and micro enterprises to obtain financial services in a lower cost and more convenient way, and better play the role of digital financial inclusion in promoting the development of these. Secondly, the government should ease the financing constraints of small and micro enterprises. Digital financial inclusion promotes the sustainable growth of small and micro enterprises by alleviating financing constraints. Therefore, we must rely on digital technologies such as the Internet of Things, big data, cloud computing, and blockchain to build a more comprehensive social financing system and credit system. In this way, information asymmetry between financing financial institutions and small and micro enterprises can be alleviated to build a fair and just business environment for these enterprises in China. Thirdly, the financial ecological environment has different impacts on different enterprises. The sustainable growth ability of small and micro enterprises in private enterprises, high-tech industries, and competitive markets is more likely to be affected by digital financial inclusion. Therefore, the government should guide social capital to provide financial credit support to such enterprises and optimize the allocation of financial resources.

\subsection{Research Limitations and Future Research}

This study has certain limitations. First, due to the limited access to data, this study mainly uses the data of China's New Third Board Market listed companies as the sample and draws the key conclusion that digital financial inclusion helps promote the sustainable growth of small and micro enterprises. Technically, unlisted small and micro enterprises should be included if the conclusion were to be applied to all small and micro enterprises in China. Second, external uncertainties such as global trade frictions, economic crises, and the current outbreak of COVID-19 can also impact the sustainable growth of small and micro enterprises. Finally, this study mainly explores the mechanism of digital financial inclusion on the sustainable growth of small and micro enterprises from the perspective of alleviating financing constraints, but other potential mechanisms, including the investment in innovation, social responsibility disclosures, and internal management have yet to be examined. Therefore, further studies could focus on expanding the research sample by including more small and micro enterprises in China, collecting the data of unlisted enterprises, incorporating external factors such as economic and policy uncertainties into the research variables, and exploring how digital financial inclusion promotes the sustainable growth of small and micro enterprises.

Author Contributions: Conceptualization: Y.Z.; Methodology: Y.Z.; Software: L.Y.; Formal analysis: L.Y.; Writing: L.Y. All authors have read and agreed to the published version of the manuscript.

Funding: This research was funded by Chinese National Funding of Social Sciences, grant number No.15AGL008.

Conflicts of Interest: No potential conflict of interest was reported by the authors.

\section{References}

1. Alejandro, E.E.; Luz, S.P.; Esther, S.P. The Influence of Top Management Teams in the Strategic Orientation and Performance of Small and Medium-sized Enterprises. Br. J. Manag. 2009, 20, 581-597.

2. Wen, S.; Fang, Y. An Empirical Study on the Relationship between Corporate Social Responsibility and Financial Performance: Panel Data Analysis from the Perspective of Stakeholders. China Ind. Econ. 2008, 10, 150-160.

3. Yang, H.; Deng, Q. Research on Social Responsibility and Performance of State-owned Enterprises-From the Perspective of Sustainable Growth. J. Zhongnan Univ. Econ. Law 2011, 1, 120-127.

4. Jiang, Y.; Zhang, L. Characteristics of Top Managers and Sustainable Growth of Small and Medium-sized Enterprises: An Analysis Based on Management Defense Theory. Econ. Rev. 2012, 5, 69-77.

5. Liu, Z.; Zhou, Z. Technical Director, R \& D Investment and Sustainable Growth. Bus. Econ. Manag. 2019, 8, $72-84$. 
6. He, P.; Sun, Y.; Li, T.; Yuan, Y.; Chen, Y. Directors' Characteristics and Operating Performance-An Empirical Study Based on China's New Third Board Enterprise. Account. Res. 2019, 11, 49-55.

7. Cui, X.; Wang, L.; Xu, H. Research on the Relationship between Enterprise Growth and Financial Crisis-Based on Empirical Evidence from Listed Companies in the Telecommunications and Computer Industry. Account. Res. 2007, 12, 55-62, 97.

8. Li, Y.; Zhang, T. Evaluation of Financial Eco-Environment in China (2008-2009); Finance Press: Beijing, China, 2009.

9. Buchak, G.; Matvos, G.; Piskorski, T.; Seru, A. Fintech, Regulatory Arbitrage, and the Rise of Shadow Banks. J. Financ. Econ. 2018, 130, 453-483. [CrossRef]

10. Wu, S. Risk Problems, Regulatory Challenges and Development Suggestions for Digital Financial Inclusion. Technol. Econ. Manag. Res. 2019, 1, 66-69.

11. Xie, P.; Zou, C. Research on Internet Finance Models. Financ. Res. 2012, 12, 11-22.

12. Li, J. Thoughts on Internet Finance. Manag. World 2015, 7, 1-7. [CrossRef]

13. Guo, F.; Wang, J.; Wang, F.; Kong, T.; Zhang, X.; Cheng, Z. Evaluating the Development of China's Digital Financial Inclusion: Index Compilation and Spatial Characteristics; Working Paper of Digital Finance Research Center; Peking University: Peking, China, 2019.

14. Higgins, R. Financial Management Analysis, 6th ed.; Peking University Press: Beijing, China, 2003; pp. 84-89.

15. Van Horn, J.C. Song Fengming and Other Translations. In Financial Management and Policy Tutorial, 10th ed.; Huaxia Publishing House: Beijing, China, 2000; pp. 308-314.

16. Rappoport, A. Creating Shareholder Value; The Free Press: New York, NY, USA, 1980; pp. 135-147.

17. Colley, J.L. Corporate Strategy; Finance and Economics Press: Beijing, China, 2003.

18. Xiaofeng, Y.; Zhifang, W. Financial Sustainable Growth Model and Its Application. Account. Res. 2003, 6, 48-50.

19. Xingjian, F.; Xiaoyu, G. Reconstruction of Sustainable Growth Model of Enterprises and Its Enlightenment. Account. Res. 2007, 5, 39-45, 95.

20. Yuchun, W.; Guiru, H. Examining the Sustainable Growth of Listed Companies from a Financial Perspective: Empirical Research from Listed Companies in Information Technology. Account. Res. 2007, 2, 65-71, 92.

21. Guliang, T.; You, Y. Comparative Analysis and Case Verification of Sustainable Growth Model. Account. Res. 2005, 8, 50-55.

22. Dongwei, S.; Yangru, W. Econometric Model and Empirical Analysis of the Sustainable Development of Listed Companies in China. Econ. Res. 2005, 1, 106-116.

23. Xiaobo, H.; Yuanyuan, Z. Corporate Profit Structure and Sustainable Growth-Empirical Evidence Based on A-share Competitive Listed Companies. J. Nanjing Inst. Audit. 2012, 9, $26-33$.

24. Tang, L. Empirical Research on Profit Quality and Sustainable Growth Ability; Kunming University of Technology: Kunming, China, 2017.

25. Xiaoyuan, M. On Enterprise Environment and Sustainable Development. Manag. World 2010, 4, 1-4.

26. Jun, H.; Yang, C.; Haomiao, Z. The Impact of Corporate Environmental Ethics on the Performance of Sustainable Development: The Causes and Consequences of Proactive Environmental Management. Econ. Manag. 2011, 33, 61-68.

27. Yunguang, L.; Jieyi, P.; Taiwen, F. Research on the Impact of Lean Production and Enterprise Environmental Management on Sustainable Development Performance of Manufacturing Industry. Soft Sci. 2008, 32, 68-71, 76.

28. Desheng, S.; Hanting, F.; Mingxi, Z. Research on Financing Pain Points and Countermeasures of Small and Medium-sized Science and Technology Enterprises. China Sci. Technol. Forum 2017, 11, 93-98.

29. Bang, L.; Jianhua, Z. Can Chinese Financial Inclusion Innovation Ease the Financing Constraints of SMEs. China Sci. Technol. Forum 2018, 11, 94-105.

30. Xuesong, Q.; Yubin, D.; Linlin, C.; Sheng, F. Reform of Security Real Right System, Financing Constraints and Corporate Cash Holdings: Empirical Evidence Based on Natural Experiments of China's Property Law. Account. Res. 2019, 1, 72-78.

31. Chuntao, L.; Xuwen, Y.; Min, S.; Wei, Y. Fintech and Enterprise Innovation: Evidence from New Third Board Listed Companies. China Ind. Econ. 2020, 1, 81-98.

32. World Bank. Enterprise Surveys. Available online: http://www.enterprisesurveys.org/ (accessed on 25 April 2019). 
33. Jinpu, J. Application Analysis and Policy Recommendations of Mobile Payment to promote the development of financial inclusion. China Circ. Econ. 2014, 28, 7-10.

34. Shuanglu, L.; Peipei, L. Digital Financial Inclusion and Urban-rural Income Gap. J. Cap. Univ. Econ. Trade 2019, 21, 33-41.

35. Jinpu, J.; Tingting, H.; Tiandu, W.; Shaohua, Z.; Yan, W. Development Process and Empirical Research of Financial Inclusion in China. Shanghai Financ. 2015, 4, 12-22.

36. Jensen, M.C.; Meckling, W.H. Theory of The Firm: Managerial Behavior, Agency Costs and Ownership Structure. J. Financ. Econ. 1976, 3, 305-360. [CrossRef]

37. Qing, H. Financing policy and growth rate: Evidence from the enterprise level. J. Zhongnan Univ. Econ. Law 2008, 1, 3-9.

38. Lei, S. Financing constraints and sustainable growth. Cooper. Econ. Technol. 2010, 14, 36-38.

39. Yean, Z. An Empirical Study on the Influence of Financial Inhibition on the Financing Capacity of Chinese Enterprises. Econ. Res. 1999, 2, 15-22.

40. Ruyong, T. Empirical Research on the Connection between External Financing and Corporate Growth. Secur. Market Herald 2001, 2, 23-26.

41. Zeguang, G.; Bing, G. The Discussion on the financial Difficulties of Enterprise Growth-The Correlation Analysis of Stock Issuance, Enterprise debt and Growth. Account. Res. 2002, 7, 11-15.

42. Ping, X. Internet Finance is the Third Mode. Shanghai Econ. 2014, 7, 16.

43. Taiping, L.; Dongxu, Z. Financing Demand, Financing Constraint and Earnings Management. Account. Res. 2014, 1, 35-41.

44. Duarte, J.; Siegel, S.; Young, L. Trust and Credit: The Role of Appearance in peer-to-peer Lending. Rev. Financ. Stud. 2012, 25, 2455-2483. [CrossRef]

45. Herzenstein, M.; Sonenshein, S.; Dholakia, U.M. Tell Me a Good Story and I May Lend You Money: The Role of Narratives in peer-to-peer Lending Decisions. J. Market. Res. 2011, 48, 138-149. [CrossRef]

46. Huijuan, W.; Li, L. Research on Credit Authentication Mechanism of China's P2P Network Lending Platform-Empirical Evidence from “Everyone's Loan”. China Ind. Econ. 2014, 4, 136-147.

47. Hadlock, C.J.; Pierce, J.R. New evidence on measuring financial constraints: Moving beyond the KZ index. Rev. Financ. Stud. 2010, 23, 1909-1940. [CrossRef]

48. Huilin, Z.; Xiaoran, N. Financial Development, Deepening of the Rule of Law and Risk-taking of Listed Enterprises. Invest. Res. 2017, 36, 4-23.

49. Fusheng, Y.; Min, Z.; Fuxiu, J.; Mengjie, R. Does Corporate Governance Affect Corporate Financial Risk? Account. Res. 2008, 10, 52-59.

50. Lifeng, G. Product market competition, R\&D investment, and stock returns. J. Financ. Econ. 2015, 119, 441-455.

51. Hart, O. The Market as an Incentive Mechanism. Bell J. Econ. 1983. [CrossRef]

52. Schmidit, K. The Cost and Benefits of Privatization. J. Law Econ. Organ. 1996, 12, 1-24. [CrossRef]

53. Hermalin, B. The Effects of Competition on Executive Behavior. Rand J. Econ. 1992, 23, 350-365. [CrossRef]

54. Holmstrom, B. Moral Hazard in risk-averse teams. Rand J. Econ. 1987, 18, 428-435.

55. Shiyu, W.; Zhibin, C. Product Market Competition, Government Role and Corporate Financial Risk. J. Tianjin Univ. Financ. Econ. 2017, 37, 78-92.

56. Xiaoliang, W.; Kunru, T.; Yong, J. Research on Financial Ecological Environment and Enterprise Investment Efficiency of Government Investment and Financing Platform. Account. Res. 2019, 6, 13-19.

57. Love, I. Financial Development and Financing Constraints: International Evidence from the Structural Investment Model. Rev. Financ. Stud. 2003, 16, 765-791. [CrossRef]

58. Weimin, X.; Hongxing, F. Financial Development, Financing Constraints and Enterprise R \& D Investment. Financ. Res. 2011, 5, 171-183.

(C) 2020 by the authors. Licensee MDPI, Basel, Switzerland. This article is an open access article distributed under the terms and conditions of the Creative Commons Attribution (CC BY) license (http://creativecommons.org/licenses/by/4.0/). 